"This is the peer reviewed version of the following article:, Catalytic Oxidation of Water to Dioxygen by Mononuclear Ru Complexes Bearing a 2,6-Pyridinedicarboxylato Ligand, which has been published in final form at:

https://onlinelibrary.wiley.com/doi/10.1002/cssc.201802996

This article may be used for non-commercial purposes in accordance with Wiley Terms and Conditions for Self-Archiving."

\title{
Catalytic Oxidation of Water to Dioxygen by Mononuclear Ru Complexes Bearing a 2,6-Pyridinedicarboxylato Ligand
}

Md Asmaul Hoque, ${ }^{1}$ Jordi Benet-Bucholz, ${ }^{1}$ Antoni Llobet ${ }^{1,2}$, Carolina Gimbert-Suriñach, ${ }^{1, *}$

${ }^{1}$ Institute of Chemical Research of Catalonia (ICIQ), Barcelona Institute of Science and Technology, Av. Països Catalans 16, 43007 Tarragona, Spain.

${ }^{2}$ Universitat Autònoma de Barcelona, Departament de Química, Cerdanyola del Vallès, 08193 Barcelona, Spain. 
Abstract

The synthesis, purification and isolation of two new Ru complexes containing the tridentate dianionic meridional ligand pyridyl-2,6-dicarboxylato $\left(\mathrm{pdc}^{2-}\right)$ of general formula [Ru'I"(pdc- $\mathrm{k}^{3}-$ $\left.\mathrm{N}^{1} \mathrm{O}^{2}\right)\left(\right.$ bpy)Cl], $1^{\prime \prime \prime}$, and [Ru'(pdc- $\left.\left.\mathrm{r}^{2}-\mathrm{N}^{1} \mathrm{O}^{1}\right)(\text { bpy })_{2}\right], 2^{\prime \prime}$, (bpy is 2,2'-bipyridne) is reported. These two complexes and their derivatives have been thoroughly characterized based on spectroscopic (UV-vis, NMR) and electrochemical techniques (CV, DPV and Coulometry). Under a high anodic applied potential both complexes evolve towards the formation of new Ru-aquo species namely, $\left[\mathrm{Ru}^{\prime \prime \prime}\left(\mathrm{pdc}-\mathrm{K}^{3}-\mathrm{N}^{1} \mathrm{O}^{2}\right)(\mathrm{bpy})\left(\mathrm{OH}_{2}\right)\right]^{+}, 1-\mathrm{O}$, and $\left[\mathrm{Ru}^{\mathrm{IV}}(\mathrm{O})\left(\mathrm{pdc}-\mathrm{K}^{2}-\mathrm{N}^{1} \mathrm{O}^{1}\right)(\mathrm{bpy})_{2}\right], 2-0$. These two new complexes are active catalysts for the oxidation of water to dioxygen and their catalytic activity is analyzed based on electrochemical techniques. A TOF $\max =2.4-3.4 \times 10^{3} \mathrm{~s}^{-1}$, has been calculated for 2-0. 
Graphical Abstract

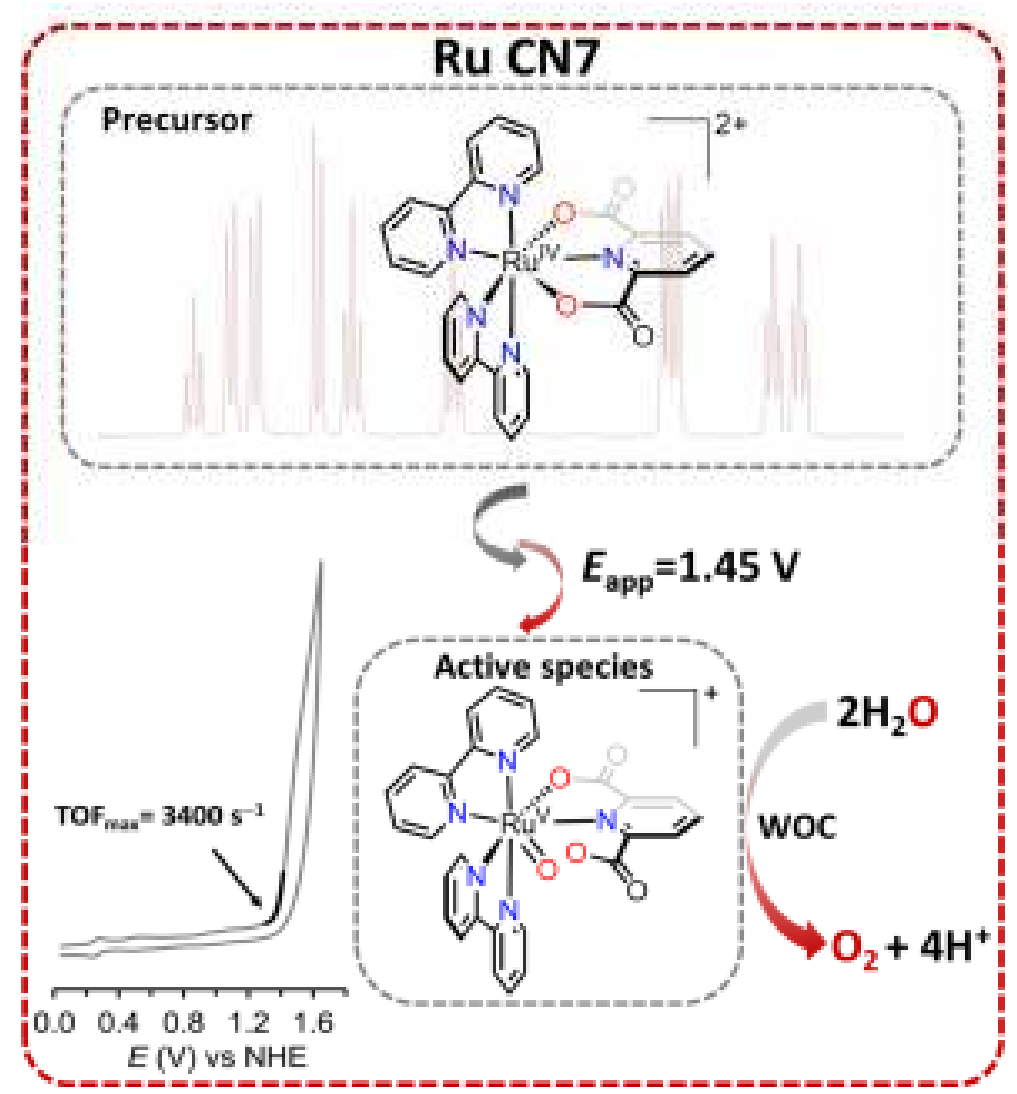

Keywords

Water oxidation, redox properties transition metal complexes, Ru complexes, redox catalysis 


\section{1-Introduction}

Water oxidation (WO) catalysis is one of the key process involved in the light induced water splitting (WS) reaction. This hydrogen as a clean fuel from an inexhaustible source of energy, sunlight ${ }^{1}$. The overall reaction is depicted in Eq. 1, that can be split in the respective two half reactions in Eq. 2 (WO) and Eq. 3 for proton reduction (PR). ${ }^{2}$ Given the beneficial impact of such a sustainable process on our society, the development of efficient catalysts to perform the WO reaction has experienced increasing interest. ${ }^{3-5}$ Among the most efficient catalysts described to date, ruthenium coordination complexes containing flexible, adaptative, multidentate and equatorial (FAME) ligands have shown to perform remarkably well. ${ }^{3,6}$ Another key feature of the best performing WO catalysts is the presence of carboxylate groups in the coordination sphere of the metal center, providing stability to the metal high oxidation states and lowering the overpotential of the reaction. $\cdot^{7-9}$ In addition, the presence of dangling carboxylate group, strategically situated so that it can intramolecularly accept a proton at the water nucleophilic attack stage, significantly reduces the energy of activation at this step and thus greatly increases reaction rate..$^{3,7,10}$

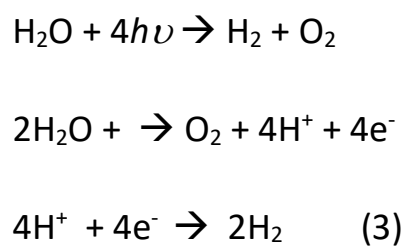

Ruthenium complexes have also been crucial to understand the mechanistic pathways responsible for the $0-\mathrm{O}^{11-13}$ bond formation and how the coordination sphere around the metal center influence these pathways. Other factors such as the $\mathrm{pK}_{\mathrm{a}}$ of ruthenium aquo $\left(\mathrm{Ru}-\mathrm{OH}_{2}\right)$ intermediate species have also been shown to strongly impact the performance of the water oxidation catalysts. ${ }^{14,15}$ All these insights are of paramount importance because they have allowed the rational design of catalysts that nowadays can perform as fast as $7,900 \mathrm{~s}^{-1}$ at neutral $\mathrm{pH}^{7}$

In this work, we explore the water oxidation catalytic activity of Ru complexes containing the meridional tridentate dianionic ligand 2,6-pyridinedicarboxylato $\left(\mathrm{pdc}^{2-}\right)$, which can show different coordination modes. ${ }^{16}$ For instance, it can coordinate in a tridentate $k-\mathrm{N}^{1} \mathrm{O}^{2}$ meridional 
fashion and provide a strong sigma donation to the metal center ${ }^{16-18}$ but also it can bind in a bidentate $\mathrm{k}-\mathrm{N}^{1} \mathrm{O}^{1}$ mode leaving a pendant carboxylate. ${ }^{16}$

Here on we report the preparation, purification and isolation of two new Ru complexes $\left[\mathrm{Ru}^{\prime \prime \prime}\left(\mathrm{pdc}-\mathrm{K}^{3}-\mathrm{N}^{1} \mathrm{O}^{2}\right)(\mathrm{bpy}) \mathrm{Cl}\right], \mathbf{1}^{1 \prime \prime}$, and $\left[\mathrm{Ru} \mathrm{u}^{\prime \prime}\left(\mathrm{pdc}-\mathrm{K}^{2}-\mathrm{N}^{1} \mathrm{O}^{1}\right)(\mathrm{bpy})_{2}\right], \mathbf{2}^{\prime \prime}$, shown in Scheme 1 , that in addition to the $\mathrm{pdc}^{2-}$ ligand also contain one or two neutral didentate $2,2^{\prime}$-bipyridne (bpy) ligands respectively. We have studied the spectroscopic, redox and structural properties of these two complexes and we have also shown that are precursors to Ru complexes capable of catalytically oxidize water to dioxygen. The activity of the catalysts is evaluated based on electrochemical techniques. 


\section{2-Experimental Section}

Materials. $\mathrm{RuCl}_{3} \cdot \times \mathrm{H}_{2} \mathrm{O}$ was purchased from Alfa-Aesar. The precursor complex $\left[\mathrm{RuCl}_{2}(\mathrm{DMSO})_{4}\right]$ was prepared according to a reported procedure. ${ }^{19}$ 2,6-pyridindicarboxylic acid $\left(\mathrm{H}_{2} \mathrm{pdc}\right)$ and other chemicals were obtained from Aldrich and used as received. Solvents were dried with a SPS $^{\circledR}$ system and degassed by bubbling nitrogen before starting the reactions. High purity deionized water used for the electrochemistry experiments was obtained by passing distilled water through a nanopure Mili-Q water purification system. For other spectroscopic and electrochemical studies, HPLC-grade solvents were used.

Instrumentation and methods. A Bruker Avance $500 \mathrm{MHz}$ were used to carry out NMR spectroscopy. ESI-Mass spectra were recorded using micromass Q-TOF mass spectrometer. Elemental analyses were carried out on Perkin-Elmer $240 \mathrm{C}$ elemental analyzer. The EPR experiments were carried out at $4 \mathrm{~K}$ on frozen solutions by using a $\mathrm{X}$-band spectrometer (Bruker ELEXYS E580). The $\mathrm{pH}$ of the solutions was determined by a pHmeter (CRISON, Basic $20^{+}$) calibrated before measurements through standard solutions at $\mathrm{pH} 4.01,7.00$ and 9.21 . Oxygen evolution was analyzed with a gas phase Clark type oxygen electrode (Unisense Ox-N needle microsensor) and calibrated by the addition of small quantities of oxygen (99\%) at the end of the experiment. All electrochemical experiments were performed in an IJ-Cambria CHI-660 potentiostat using a three-electrode one compartment cell for cyclic voltammetry (CV) and differential pulse voltammetry (DPV) or two compartment cell for bulk electrolysis. $E_{1 / 2}$ values reported in this work were estimated from CV experiments as the average of the oxidative and reductive peak potentials $\left(E_{\mathrm{p}, \mathrm{a}}+E_{\mathrm{p}, \mathrm{c}}\right) / 2$ or from DPV. The Reference Electrode (RE) was $\mathrm{Hg} / \mathrm{Hg}_{2} \mathrm{SO}_{4}$ $\left(\mathrm{K}_{2} \mathrm{SO}_{4}\right.$ saturated) and potentials were converted to NHE by adding $0.65 \mathrm{~V}$. Glassy carbon disk ( $\phi$ $\left.=0.3 \mathrm{~cm}, \mathrm{~S}=0.07 \mathrm{~cm}^{2}\right), \mathrm{Pt}$ disk and $\mathrm{Hg} / \mathrm{Hg}_{2} \mathrm{SO}_{4}\left(\mathrm{~K}_{2} \mathrm{SO}_{4}\right.$ saturated) were used as Working Electrode (WE), Counter Electrode (CE) and Reference Electrode (RE) respectively, unless explicitly mentioned. Glassy carbon electrodes were polished with $0.05 \mu \mathrm{m}$ alumina $\left(\mathrm{Al}_{2} \mathrm{O}_{3}\right)$ and rinsed with water. CVs and DPVs were iR compensated by the potentiostat in all the measurements. $C V s$ were recorded at $100 \mathrm{mV} \cdot \mathrm{s}^{-1}$ scan rate. DPV parameters were $\Delta E=4 \mathrm{mV}$, Amplitude $=0 \mathrm{mV}$, Pulse width $=5 \mathrm{~s}$, Sampling width $=0.0167 \mathrm{~s}$, Pulse period $=5 \mathrm{~s}$. The complexes were dissolved in dichloromethane or acetone containing $\left[\left(n-\mathrm{Bu}_{4}{ }_{4} \mathrm{~N}\right]\left[\mathrm{PF}_{6}\right](0.1 \mathrm{M})\right.$ as supporting electrolyte. In aqueous solution the electrochemical experiments were carried out in $I=0.1 \mathrm{M}$ phosphate buffer solutions with desired $\mathrm{pH}$. The Pourbaix diagrams were built using the following buffers: sodium dihydrogen phosphate/phosphoric acid up to $\mathrm{pH}=4\left(\mathrm{pK}_{\mathrm{a}}=2.12\right)$, sodium hydrogen phosphate/ sodium dihydrogen phosphate up to $\mathrm{pH}=9\left(\mathrm{pK}_{\mathrm{a}}=7.67\right)$, sodium hydrogen phosphate/sodium phosphate up to $\mathrm{pH}=13\left(\mathrm{pK}_{\mathrm{a}}=12.12\right)$ and also $0.1 \mathrm{M} \mathrm{CF}_{3} \mathrm{SO}_{3} \mathrm{H}$ for $\mathrm{pH}=1.0$. 
For routine bulk electrolysis experiments in figure $4 \mathrm{~b}$ bottom left, a Pt grid was used as a WE, another Pt grid as a $\mathrm{CE}$ and a $\mathrm{Hg} / \mathrm{Hg}_{2} \mathrm{SO}_{4}\left(\mathrm{~K}_{2} \mathrm{SO}_{4}\right.$ saturated) as a RE. For the bulk electrolysis experiment for oxygen detection, a glassy carbon rod $\left(S=8.2 \mathrm{~cm}^{2}\right)$ was used as a working electrode and $\mathrm{Ag} / \mathrm{AgCl}$ (sat. $\mathrm{KCl}$ ) as a $\mathrm{RE}$.

For Figure S11, to generate $\left[\mathrm{Ru}^{\prime \prime \prime}\left(\mathrm{pdc}-\mathrm{K}^{3}-\mathrm{N}^{1} \mathrm{O}^{2}\right)(\mathrm{bpy})\left(\mathrm{OH}_{2}\right)\right]^{+}, 1-0$, complex from $1 \mathrm{mM}$ of $\left[\mathrm{Ru}^{\prime \prime \prime}\left(\mathrm{pdc}-\mathrm{K}^{3}-\mathrm{N}^{1} \mathrm{O}^{2}\right)(\mathrm{bpy}) \mathrm{Cl}\right], \mathbf{1}^{\prime \prime \prime}$, bulk electrolysis experiment was carried out in three-electrode one compartment cell for $5 \mathrm{~min}$ at $E_{\mathrm{app}}=1.6 \mathrm{~V}$ without stirring. A glassy carbon disk was used as a WE, Pt disk as a $\mathrm{CE}$ and a $\mathrm{Hg} / \mathrm{Hg}_{2} \mathrm{SO}_{4}\left(\mathrm{~K}_{2} \mathrm{SO}_{4}\right.$ saturated) as a RE. For figure $\mathrm{S} 15$, to see the coordination of DMSO, $\left[R u^{\prime \prime}\left(p d c-\kappa^{2}-N^{1} O^{1}\right)(b p y)(d m s o) C l\right]$, to the complex $\left[R u^{\prime \prime \prime}\left(p d c-k^{3}-\right.\right.$ $\left.\mathrm{N}^{1} \mathrm{O}^{2}\right)\left(\right.$ bpy)Cl], $\mathbf{1}^{\prime \prime \prime}$, bulk electrolysis experiment was carried out in three-electrode one compartment cell for $2 \mathrm{~min}$ at $E_{\text {app }}=0 \mathrm{~V}$ without stirring. A glassy carbon disk was used as a WE, Pt disk as a $\mathrm{CE}$ and a $\mathrm{Hg} / \mathrm{Hg}_{2} \mathrm{SO}_{4}\left(\mathrm{~K}_{2} \mathrm{SO}_{4}\right.$ saturated) as a $\mathrm{RE}$. $i \mathrm{R}$ compensation by the potentiostat was not applied in this technique.

\section{Single Crystal X-Ray Structure Determinations}

Crystal preparation: Crystals of $\left[\mathrm{Ru}^{\prime \prime \prime}\left(\mathrm{pdc}-\mathrm{k}^{3}-\mathrm{N}^{1} \mathrm{O}^{2}\right)(\mathrm{bpy}) \mathrm{Cl}\right], \mathbf{1}^{\prime \prime \prime}$, was obtained from reaction in methanol solvent. $\left[R u^{\prime \prime}\left(p d c-\kappa^{2}-N^{1} O^{1}\right)(b p y)_{2}\right], 2^{\prime \prime}$, and $\left[R u^{\prime \prime \prime}\left(H p d c-\kappa^{2}-N^{1} O^{1}\right)(b p y)_{2}\right]^{2+}, 2^{\prime \prime \prime}$, were grown by slow evaporation of methanol:hexane and water:acetonitrile respectively. The measured crystals were prepared under inert conditions immersed in perfluoropolyether as protecting oil for manipulation.

Data Collection: Crystal structure determination for compounds $\mathbf{1}^{\prime \prime \prime}, \mathbf{2}^{\prime \prime}$ and $\mathbf{2}^{\text {III }}$ were carried out using a Rigaku diffractometer equipped with a Pilatus 200K area detector, a Rigaku MicroMax007HF microfocus rotating anode with $\mathrm{MoK}_{\alpha}$ radiation, Confocal Max Flux optics and an Oxford Cryosystems low temperature device Cryostream 700 plus $\left(T=-173^{\circ} \mathrm{C}\right)$. Full-sphere data collection was used with $\omega$ and $\varphi$ scans. Programs used: Data collection and reduction with CrysAlisPro ${ }^{20} \mathrm{~V} / .60 \mathrm{~A}$ and absorption correction with Scale3 Abspack scaling algorithm. ${ }^{21}$

Structure Solution and Refinement: Crystal structure solution was achieved using the computer program SHELXT..$^{22}$ Visualization was performed with the program SHELXle. ${ }^{23}$ Missing atoms were subsequently located from difference Fourier synthesis and added to the atom list. Leastsquares refinement on $\mathrm{F}^{2}$ using all measured intensities was carried out using the program SHELXL 2015. All non-hydrogen atoms were refined including anisotropic displacement parameters. 
Comments to the structures: $\left[\mathrm{Ru}\right.$ "'I $\left.\left(\mathrm{pdc}-\mathrm{r}^{3}-\mathrm{N}^{1} \mathrm{O}^{2}\right)(\mathrm{bpy}) \mathrm{Cl}\right], \mathbf{1}^{\text {III }}$ : The asymmetric unit contains one molecule of the metal complex and one methanol molecule. [Ru" $\left.\left(p d c-\kappa^{2}-N^{1} O^{1}\right)(b p y)_{2}\right], 2^{\prime \prime}:$ The asymmetric unit contains one molecule of the metal complex and two molecules of water. $\left[\mathrm{Ru}^{\prime \prime \prime}\left(\mathrm{Hpdc}-\mathrm{k}^{2}-\mathrm{N}^{1} \mathrm{O}^{1}\right)(\mathrm{bpy})_{2}\right]^{2+}, \mathbf{2}^{\text {III: }}$ The asymmetric unit contains one molecule of the metal complex, 1 1⁄2 $\mathrm{PF}_{6}$-anions, 1.75 molecules of acetonitrile and 0.25 molecules of dichloromethane. In this metal complex one of the carboxylates is protonated with 0.5 occupancy (although hydrogen atoms can be only be localized with difficulties, the distances indicate unambiguously that one of the oxygen atoms is protonated). In one of the solvent position, an acetonitrile and a dichloromethane molecule are sharing its position by disorder with a ratio of respectively $75: 25$.

Synthesis of $\left[\mathrm{Ru}^{\prime \prime \prime}\left(\mathbf{p d c}-\mathbf{k}^{3}-\mathbf{N}^{1} \mathbf{O}^{2}\right)(\mathbf{b p y}) \mathbf{C l}\right], \mathbf{1}^{\prime \prime \prime}$. In a $100 \mathrm{~mL}$ two neck round-bottom flask, $\mathrm{RuCl}_{3} . \mathrm{xH}_{2} \mathrm{O}(262 \mathrm{mg}, \mathrm{ca} .1 \mathrm{mmol})$ and $\mathrm{LiCl}(42 \mathrm{mg}, 1 \mathrm{mmol})$ were dissolved in $20 \mathrm{~mL}$ of degassed methanol. Then, a $10 \mathrm{~mL}$ degassed aqueous solution of 2,6-pyridine dicarboxylic acid (167 mg, $1 \mathrm{mmol})$ and sodium carbonate $(106 \mathrm{mg}, 1 \mathrm{mmol})$ were added slowly to the reaction mixture. After 20 minutes of stirring at room temperature, $10 \mathrm{~mL}$ of a degassed methanol solution of 2,2'-bipyridine (156 mg, $1 \mathrm{mmol}$ ) was added slowly and refluxed for 4 hours under $\mathrm{N}_{2}$ atmosphere. The resulting orange-red crystalline solid was filtered and washed with methanol and diethyl ether (320 mg, $0.70 \mathrm{mmol}$, Yield: $70 \%$ ). Single crystals were selected from this batch to perform single crystal x-ray diffraction analysis. Anal. Calc. for $\left(\mathrm{C}_{17} \mathrm{H}_{11} \mathrm{ClN}_{3} \mathrm{O}_{4} \mathrm{Ru} \cdot \mathrm{CH}_{3} \mathrm{OH}\right)$ : $\mathrm{C}$, 44.13\%; H, $3.09 \%$; N, $8.58 \%$; S. Found: C, $43.95 \%$;, $2.76 \%$; N, $8.58 \%$. ESI+-HRMS (MeOH) m/z calc. for $[\mathrm{M}+\mathrm{Na}]^{+}:$: 480.9406, found $\mathrm{m} / \mathrm{z}: 480.9376$.

Synthesis of [Ru"(pdc- $\left.\left.\mathbf{r}^{2}-\mathrm{N}^{1} \mathrm{O}^{1}\right)(\mathrm{bpy})(\mathrm{DMSO}) \mathrm{Cl}\right]$ in situ. In a NMR tube or in a UV-Vis spectroscopy cell, $20 \mu \mathrm{L}$ of trimethylamine were added to a solution of $0.5 \mathrm{~mL}\left[\mathrm{Ru}^{\prime \prime \prime}\left(\kappa^{3}-\right.\right.$ pdc)(bpy)Cl] in d6-dmso for the NMR and dmso for the UV-vis. ${ }^{1} \mathrm{H}-\mathrm{NMR}\left(500 \mathrm{MHz},\left[\mathrm{d}_{6}\right]\right.$-dimethyl sulfoxide + triethylamine) $\delta: 9.31(\mathrm{~d}, J=4.9 \mathrm{~Hz}, 1 \mathrm{H}), 8.48(\mathrm{~d}, J=5.05 \mathrm{~Hz}, 1 \mathrm{H}), 8.29(\mathrm{t}, J=8.35 \mathrm{~Hz}$, $2 \mathrm{H}), 7.88(\mathrm{t}, J=7.55 \mathrm{~Hz}, 1 \mathrm{H}), 7.81(\mathrm{~m}, 3 \mathrm{H}), 7.38(\mathrm{dd}, J=12.2 \mathrm{~Hz}$ and $5.05 \mathrm{~Hz}, 2 \mathrm{H}), 7.05(\mathrm{dd}, J=7.1$ $\mathrm{Hz}$ and $2.1 \mathrm{~Hz}, 1 \mathrm{H}) .{ }^{13} \mathrm{C}-\mathrm{NMR}\left(125 \mathrm{MHz},\left[\mathrm{d}_{6}\right]\right.$-dimethyl sulfoxide + triethylamine) $\delta: 172.3,167.8$, $164.3,161.4,161.2,155.4,152.9,150.3,137.2,134.9,134.7,124.5,123.8,123.7,122.9,121.9$, 121.4 .

Synthesis of $\left[\mathrm{Ru}^{\prime \prime \prime}\left(\mathrm{pdc}-\mathrm{K}^{3}-\mathrm{N}^{1} \mathrm{O}^{2}\right)(\mathrm{bpy})\left(\mathrm{OH}_{2}\right)\right]$ in situ, 1-O. In a $100 \mathrm{~mL}$ two neck round-bottom flask, [Ru'"(pdc- $\left.\mathrm{K}^{3}-\mathrm{N}^{1} \mathrm{O}^{2}\right)($ bpy $\left.) \mathrm{Cl}\right](100 \mathrm{mg}, 0.21 \mathrm{mmol})$ and $\mathrm{AgClO}_{4}(50 \mathrm{mg}, 0.24 \mathrm{mmol})$ in $40 \mathrm{~mL}$ of a mixture of acetone: water $(75: 25)$ were heated at reflux under $N_{2}$ atmosphere for $3 \mathrm{~h}$. The color of the solution changed from orange red to green. A CV analysis of the reaction crude 
mixture shows almost complete conversion of the starting material to a new species with a $\mathrm{Ru}(\mathrm{III} / \mathrm{II})$ couple consistent with the corresponding $\mathrm{Ru}-\mathrm{OH}_{2}$ complex (Figure S14 in the supporting information). After several attempts to purify this compound, it was not possible to isolate it in a pure form due to the formation of higher nuclearity oxo-bridged species as suggested by UVVis spectroscopy, which showed typical absorptions in the range of $650-800 \mathrm{~nm}$.

Synthesis of [Ru" $\left(\left(\mathbf{p d c}-\mathbf{K}^{2}-\mathbf{N}^{1} \mathbf{O}^{1}\right)(\mathbf{b p y})_{2}\right] \cdot 3 \mathrm{H}_{2} \mathbf{O}, \mathbf{2}^{11}$. In a $100 \mathrm{~mL}$ two neck round bottom flask $\left[\mathrm{Ru}^{\prime \prime}\left(\mathrm{pdc}-\mathrm{K}^{3}-\mathrm{N}^{1} \mathrm{O}^{2}\right)(\mathrm{Cl})(\mathrm{DMSO})_{2}\right]^{16}(560 \mathrm{mg}, 1 \mathrm{mmol})$ and 2,2'-bipyridine (312 mg, $2 \mathrm{mmol}$ ) were dissolved in degassed methanol $(40 \mathrm{~mL})$ and refluxed for 4 hours. The mixture was then evaporated to dryness and the resulting solid dissolved in $\mathrm{CH}_{2} \mathrm{Cl}_{2}$ and purified by column chromatography with neutral alumina using a mixture of $\mathrm{CH}_{2} \mathrm{Cl}_{2} / \mathrm{MeOH}(100: 5, \mathrm{v} / \mathrm{v})$ as eluent. A red color fraction was collected giving a solid identified as the product $(350 \mathrm{mg}, 0.60 \mathrm{mmol}$, Yield: $60 \%$ ). Single crystals were grown by slow evaporation of the complex in a 1:1 mixture of methanol:hexane. Anal. Calc. for $\left(\mathrm{C}_{27} \mathrm{H}_{19} \mathrm{~N}_{5} \mathrm{O}_{4} \mathrm{Ru} \cdot 3 \mathrm{H}_{2} \mathrm{O}\right): \mathrm{C}, 51.31 \% ; \mathrm{H}, 3.63 \% ; \mathrm{N}, 11.02 \%$. Found: C, $51.26 \% ; \mathrm{H}, 3.98 \%$; N, $11.07 \% .{ }^{1} \mathrm{H}-\mathrm{NMR}\left(500 \mathrm{~Hz},\left[\mathrm{~d}_{4}\right]-\right.$ Methanol) $\delta: 8.67$ (d, $\left.J=5.7 \mathrm{~Hz}, 1 \mathrm{H}\right)$, $8.60(\mathrm{~d}, J=5.6 \mathrm{~Hz}, 1 \mathrm{H}), 8.58(\mathrm{~d}, J=8.1 \mathrm{~Hz}, 1 \mathrm{H}), 8.56(\mathrm{~d}, J=8.2 \mathrm{~Hz}, 1 \mathrm{H}), 8.48(\mathrm{~d}, J=8.1 \mathrm{~Hz}, 1 \mathrm{H})$, $8.33(\mathrm{~d}, J=8 \mathrm{~Hz}, 1 \mathrm{H}), 8.09-8.06(\mathrm{~m}, 3 \mathrm{H}), 7.97(\mathrm{t}, J=7.7 \mathrm{~Hz}, 1 \mathrm{H}) .7 .85(\mathrm{td}, J=1.4$ and $7.9 \mathrm{~Hz}, 1 \mathrm{H})$, 7.75-7.70 (m, 2H ), $7.62(\mathrm{t}, J=6.5 \mathrm{~Hz}, 1 \mathrm{H}), 7.56(\mathrm{t}, J=6.4 \mathrm{~Hz}, 1 \mathrm{H}), 7.39(\mathrm{~d}, J=5.1 \mathrm{~Hz}, 1 \mathrm{H}), 7.34$ (dd, $J=1.5$ and $7.7 \mathrm{~Hz}, 1 \mathrm{H}$ ), $7.21(\mathrm{t}, J=6.6 \mathrm{~Hz}, 1 \mathrm{H}), 7.06(\mathrm{t}, J=6.7 \mathrm{~Hz}, 1 \mathrm{H}) .{ }^{13} \mathrm{C}-\mathrm{NMR}(500 \mathrm{MHz}$, [d $\mathrm{d}_{4}$ ]-Methanol) $\delta$ : 175.6, 170.7, 165.8, 160.9, 160.4, 160.0, 159.4, 155.5, 154.8, 152.9, 152.5, 150.6, 139.2, 137.8, 137.7, 137.5, 136.3, 127.9, 127.4, 127.4, 126.6, 126.4, 126.4, 124.5, 124.3, 124.3, 123.8. (ESI+-HRMS; MeOH) m/z calc. for [M] ${ }^{+}: 580.0585$, found m/z: 580.0563 .

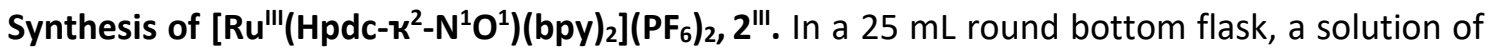
cerium(IV) ammonium nitrate (21 mM, $1.05 \mathrm{eq}, 1 \mathrm{~mL}$ in $\mathrm{pH} 1$ ) was added dropwise to a solution of $\left[R u^{\prime \prime}\left(p d c-\mathrm{K}^{2}-\mathrm{N}^{1} \mathrm{O}^{1}\right)(\mathrm{bpy})_{2}\right]$ in water $(2.0 \mathrm{mM}, 10 \mathrm{~mL})$ and the mixture was stirred at room temperature for 15 minutes. A green color precipitate was obtained when a saturated aqueous solution of $\mathrm{KPF}_{6}$ was added. The solid was filtered and washed with water, methanol and diethyl ether (10 mg, $0.0135 \mathrm{mmol}$, Yield: 65\%). Single crystals were obtained from slow evaporation of a solution in a mixture of water and acetonitrile.

Synthesis of $\left[\mathbf{R u}^{\mathrm{IV}}\left(\mathbf{p d c}-\mathbf{K}^{3}-\mathbf{N}^{1} \mathbf{O}^{2}\right)(\mathbf{b p y})_{2}\right]^{2+}, \mathbf{2}^{\text {IV }}$. Inside a NMR tube, a solution of cerium(IV) ammonium nitrate ( $42 \mathrm{mM}, 2.1 \mathrm{eq}, 0.1 \mathrm{~mL}$ in pD1) was added dropwise to a solution of [Ru"(pdc$\left.\left.\mathrm{K}^{2}-\mathrm{N}^{1} \mathrm{O}^{1}\right)(\text { bpy })_{2}\right]$ in deuterated water $(2 \mathrm{mM}, 1.0 \mathrm{~mL})$ and the mixture was stirred for 5 minutes. ${ }^{1} \mathrm{H}-\mathrm{NMR}\left(500 \mathrm{MHz},\left[\mathrm{d}_{2}\right]\right.$-water) $\delta: 8.85(\mathrm{t}, J=7.7 \mathrm{~Hz}, 1 \mathrm{H}), 8.77(\mathrm{~d}, J=8.1 \mathrm{~Hz}, 2 \mathrm{H}), 8.72(\mathrm{~d}, J=8.2$ $\mathrm{Hz}, 2 \mathrm{H}), 8.59(\mathrm{~d}, J=7.7 \mathrm{~Hz}, 2 \mathrm{H}), 8.52(\mathrm{t}, J=7.9 \mathrm{~Hz}, 2 \mathrm{H}), 8.31(\mathrm{t}, J=7.9 \mathrm{~Hz}, 2 \mathrm{H}), 7.87-7.83(\mathrm{~m}, 4 \mathrm{H})$, 
$7.64(\mathrm{t}, J=6.8 \mathrm{~Hz}, 2 \mathrm{H}) .7 .58(\mathrm{t}, J=6.7 \mathrm{~Hz}, 2 \mathrm{H}) .{ }^{13} \mathrm{C}-\mathrm{NMR}\left(500 \mathrm{MHz},\left[\mathrm{d}_{2}\right]\right.$-water) $\delta: 168.1,155.1$, $151.5,149.9,148.9,147.7,147.1,144.8,142.9,133.9,129.9,128.5,127.2,126.6$. 


\section{3-Results and discussion}

\subsection{Synthesis, spectroscopic and structural characterization}

The complex $1^{\text {III }}$ was synthesized by slow addition of an aqueous solution of sodium 2,6pyridindicarboxylate to a $\mathrm{MeOH}$ solution of the ruthenium precursor $\mathrm{RuCl}_{3} . \times \mathrm{H}_{2} \mathrm{O}$ followed by addition of 1 equivalent of bpy also in $\mathrm{MeOH}$ as indicated in Scheme 1. The final solution was refluxed for $4 \mathrm{~h}$ and on cooling an orange-red crystalline solid of the desired complex precipitates with $70 \%$ yield. Crystals suitable for single crystal $x$-ray diffraction studies were obtained and its molecular structure is shown in Figure $1 \mathrm{~A}$. It has a highly distorted octahedral geometry due to the strain imposed by the pdc- meridional ligand with O-Ru-O angle of $157^{\circ}$ as opposed to the $180^{\circ}$ expected for an ideal octahedron. It shows similar bond distances and angles to those reported for related complexes. ${ }^{16-18}$

Reduction of $\mathbf{1}^{\prime \prime \prime}$ in DMSO with $\mathrm{NEt}_{3}$, generates a new complex, [Ru" $\left(\right.$ pdc- $\mathrm{K}^{2}$ -

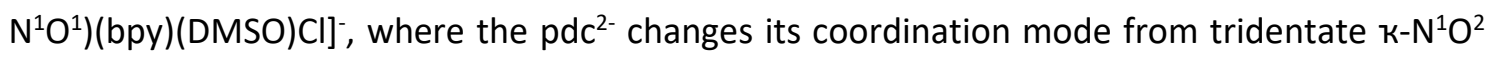
to bidentate $\mathrm{K}-\mathrm{N}^{1} \mathrm{O}^{1}$ as evidenced by $\mathrm{NMR}$ spectroscopy and Cyclic Voltammetry (CV) experiments (Figures S1 and S15 in the SI). As a consequence of the DMSO coordination the complex loses its Cs symmetry and thus all pdc ${ }^{2-}$ proton resonances are different.

On the other hand, complex $\mathbf{2}^{\prime \prime}$ was prepared in $60 \%$ yield by reacting the ruthenium precursor $\left[\mathrm{Ru}^{\prime \prime}\left(\mathrm{K}^{3}-\mathrm{N}^{1} \mathrm{O}^{2}\right)(\mathrm{Cl})(\mathrm{DMSO})_{2}\right]^{-16}$ dissolved in $\mathrm{MeOH}$ with 2 equivalents of bpy ligand under reflux. The ${ }^{1} \mathrm{H}$ NMR spectrum of the product shows the non symmetric nature of the complex with two sets of resonances for the bpy ligands as well as the corresponding non symmetric resonances for the pdc ${ }^{2-}$ protons, in agreement with the bidentate $\mathrm{K}^{-} \mathrm{N}^{1} \mathrm{O}^{1}$ coordination mode of the latter (Figure 2 and Figures S3-S4 in the supporting information). Upon oxidation with 1 equivalent of cerium(IV) ammonium nitrate (Ce(IV)), the corresponding Ru(III) derivative, [Ru'l'(Hpdc- $\mathrm{k}^{2}-$ $\left.\left.\mathrm{N}^{1} \mathrm{O}^{1}\right)(\mathrm{bpy})_{2}\right]^{2+}, \mathbf{2}^{\text {III }}$, was isolated.

Single crystals of both the Ru(II) and Ru(III) species were obtained and their ORTEP structures are shown in Figures $1 B$ and $1 C$, respectively. Complex $2^{\prime \prime}$ displays the typical slightly distorted octahedral geometry around the ruthenium, as expected for low-spin $d^{6} \mathrm{Ru}(\mathrm{II})$ ion. ${ }^{24-26}$ The bpy ligands occupy both axial and equatorial positions assuming the $\mathrm{k}-\mathrm{N}^{1} \mathrm{O}^{1}-\mathrm{pdc}^{2-}$ ligands binds in the equatorial plane, with a dangling carboxylate not bonded to Ru.

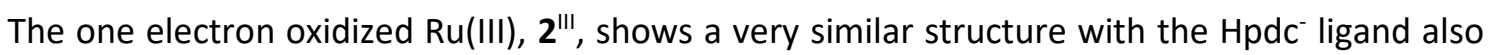
coordinating in a bidentate $\kappa-\mathrm{N}^{1} \mathrm{O}^{1}$ mode but with the nonbonding carboxylate protonated. The 
Ru-O bond distance of the Ru(III) compound is slightly shorter than that of its parent $\mathrm{Ru}(\mathrm{II})$ complex, average 2.00 (1) Åvs. 2.08 (1) $\AA$, respectively, as expected.

The addition of two equivalents of $\mathrm{Ce}(\mathrm{IV})$ to a solution of $\mathbf{2}^{\text {"I }}$ generates the $\mathrm{Ru}(\mathrm{IV})$ derivative, $\left[\mathrm{Ru}^{\mathrm{IV}}\left(\mathrm{pdc}-\mathrm{K}^{3}-\mathrm{N}^{1} \mathrm{O}^{2}\right)(\mathrm{bpy})_{2}\right]^{2+}, \mathbf{2}^{\mathrm{IV}}$, which slowly converts to the $\mathrm{Ru}(\mathrm{III})$ compound over time as monitored by NMR spectroscopy (see Figures S7), hindering the formation of high quality crystals suitable for single crystal $x$-ray diffraction. However, it was possible to fully characterize the Ru(IV) species by NMR and UV-Vis spectroscopy (Figure 2, Figures S6 and S9). All the analysis are consistent with a diamagnetic compound, corresponding to a low-spin $\mathrm{d}^{4} \mathrm{Ru}(\mathrm{IV})$ center with a $\left(d_{x z}, d_{y z}\right)^{4}$ electronic configuration and pentagonal bipyramidal geometry. ${ }^{15,} 27$ [Ru ${ }^{1 \mathrm{~V}}\left(\right.$ pdc- $\mathrm{K}^{3}-$ $\left.\left.\mathrm{N}^{1} \mathrm{O}^{2}\right)(\text { bpy })_{2}\right]^{2+}$ shows less number of resonances in the ${ }^{1} \mathrm{H}$ NMR spectra compared to its $\mathrm{Ru}(\mathrm{II})$ derivative $\left[\mathrm{Ru} \mathrm{u}^{\prime \prime}\left(\mathrm{pdc}-\mathrm{k}^{2}-\mathrm{N}^{1} \mathrm{O}^{1}\right)(\mathrm{bpy})_{2}\right]$ in agreement to the symmetry increase. In addition, they are shifted to lower field in accordance with the higher oxidation state of the Ru center.

Complex $2^{111}$ is low spin $d^{5}$ with an unpaired electron. As a consequence, all resonances in the ${ }^{1} \mathrm{H}$ NMR spectrum are broadened and highly shifted with regard to the Ru(II) analogue (Figure S5a in the supporting information). On the other hand, it exhibits typical EPR features of unsymmetrical $\mathrm{Ru}(\mathrm{III})$ complex with $\mathrm{g}_{\mathrm{x}}=2.69, \mathrm{~g}_{\mathrm{y}}=2.42, \mathrm{~g}_{z}=2.04$ (Figure $\mathrm{S} 5 \mathrm{c}$ in the supporting information). The large $g$ anisotropy and the deviation of the average $g$ factor from the free electron value of 2.0023 point to significant contributions from the heavy metal with its high spin-orbit coupling constant to the spin distribution. ${ }^{28,29}$ The Ru(III) chlorido complex $\mathbf{1}^{111}$, also shows a characteristic signal of the corresponding unpaired electron, but with a broader signature (Figure S5e in the supporting information). ${ }^{24}$ Both $\mathrm{Ru}(\mathrm{II})$ and Ru(IV) derivatives, $\mathbf{2}^{\text {II }}$ and $2^{\mathrm{IV}}$, are EPR-silent as expected for complexes with no unpaired electrons.

The UV-vis spectra of complexes $\mathbf{2}^{\prime \prime}, \mathbf{2}^{\mathrm{III}}$ and $\mathbf{2}^{\mathrm{IV}}$ were recorded in $0.1 \mathrm{M}$ triflic acid aqueous solutions ( $\mathrm{pH}$ 1.0) (Figure S9 in the supporting information). Typical Ru-bpy metal to ligand charge transfer (MLCT) bands are observed in the 380-550 $\mathrm{nm}$ range for the $\mathrm{Ru}(\mathrm{II})$ compound, where as a single transition at $360 \mathrm{~nm}$ is observed in that range of the spectrum for $\mathrm{Ru}(\mathrm{III})$, which is essentially featureless for Ru(IV). Analogous spectra could be obtained by spectrophotometric redox titration of $2^{11}$ with $\mathrm{Ce}(\mathrm{IV})$, exhibiting isosbestic points as displayed in the Figure S10 in the supporting information. 


\subsection{Electrochemical characterization}

The electrochemical behavior of complexes $\mathbf{1}^{\text {III }}$ and $\mathbf{2}^{\text {"I }}$ were analyzed by cyclic voltammetry (CV), differential pulse voltammetry (DPV) and bulk electrolysis experiments in dichloromethane (DCM) containing $0.1 \mathrm{M}$ of $\left[(n-\mathrm{Bu})_{4} \mathrm{~N}\right]\left[\mathrm{PF}_{6}\right](\mathrm{TBAH})$ and $0.1 \mathrm{M}$ ionic strength buffered aqueous solutions at different pHs. All redox potentials reported in this work are referred to the NHE electrode.

In DCM complex $1^{\text {III }}$ shows a reversible redox wave at $E_{1 / 2}=0.31 \mathrm{~V}(\Delta E=75 \mathrm{mV})$ attributed to the $\mathrm{Ru}(I I I / I)$ couple (Figure 3, left). On the other hand complex 2" shows two chemically reversible and electrochemically quasi-reversible waves at $E_{1 / 2}=1.05 \mathrm{~V}(\Delta \mathrm{E}=62 \mathrm{mV})$ and $E_{1 / 2}=1.32 \mathrm{~V}(\Delta \mathrm{E}=$ $120 \mathrm{mV}$ ) attributed to the $\mathrm{Ru}(\mathrm{III} / \mathrm{II})$ and $\mathrm{Ru}(\mathrm{IV} / \mathrm{III})$ couples respectively (Figure 3, right). ${ }^{30}$ The relatively easy access to the IV/III redox potential at only $270 \mathrm{mV}$ above the III/II is a clear indication of the 7 coordinated nature of the oxidized compound, as already been proven by NMR spectroscopy (Figure 2).

The chlorido complex $\mathbf{1}^{\text {III }}$ in aqueous solution at a $\mathrm{pH} 7$ phosphate buffer (phbf), shows a Ru(III/II) redox wave at $E_{1 / 2}=0.44 \mathrm{~V}(\Delta \mathrm{E}=65 \mathrm{mV})$ (Figure $\mathrm{S} 11$ in the supporting information) and a second wave at $1.45 \mathrm{~V}$ which is chemically irreversible. It thus indicates that $\mathrm{Ru}(\mathrm{IV})-\mathrm{Cl}$ complex is not stable and undergoes oxidative $\mathrm{Ru}-\mathrm{Cl}$ degradation to form most likely $\mathrm{Cl}_{2}(\mathrm{~g})$ as has been proposed for related complexes. This produces the in situ generation of the $\mathrm{Ru}-\mathrm{OH}_{2}$ complex, $\left[\mathrm{Ru}^{\prime \prime}\left(\text { pdc- } \mathrm{K}^{3}-\mathrm{N}^{1} \mathrm{O}^{2}\right)(\mathrm{bpy})\left(\mathrm{H}_{2} \mathrm{O}\right)\right]^{-}$that can act as a water oxidation catalyst. Indeed, a bulk electrolysis experiments of $\mathbf{1}^{\text {III }}$ at $1.6 \mathrm{~V}$ for 5 minutes at $\mathrm{pH} 7$ involved a charge of $7.2 \mathrm{mC}$, which implies 0.05 mols of electrons per mol of $\mathbf{1}^{\prime \prime \prime}$. The shape of the current vs. time is in agreement with the in situ generation of a water oxidation catalyst. A CV and DPV analysis of the solution after the bulk electrolysis experiments reveals the generation of three new waves at $E=0.27 \mathrm{~V}$, $E=0.80 \mathrm{~V}$ and $E=1.41 \mathrm{~V}$ that can be tentatively assigned to the III/II, IV/III and V/IV couples of $\left[\mathrm{Ru}^{\prime \prime}\left(\text { pdc- } \mathrm{k}^{3}-\mathrm{N}^{1} \mathrm{O}^{2}\right)(\mathrm{bpy})\left(\mathrm{H}_{2} \mathrm{O}\right)\right]^{-}$respectively. The latter one being responsible for the catalytic phenomenon. 
On the other hand, the $\mathrm{CV}$ of complex $\mathbf{2}^{\prime \prime}$ at $\mathrm{pH} 7$ shows two $\mathrm{pH}$ independent redox waves at $E_{1 / 2}$ $=0.89 \mathrm{~V}(\Delta E=90 \mathrm{mV})$ and $1.23 \mathrm{~V}(\Delta E=70 \mathrm{mV})$ associated with the III/II and IV/III couples as can be observed in Figure 4A. Figure 4B shows the effect of carrying out 100 repetitive $\mathrm{CV}$ within the potential range $0-1.6 \mathrm{~V}$ at the same $\mathrm{pH}$. As can be observed in the inset as the number of cycles increases new small waves appear that are indicated with blue arrows together with the presence of a large electrocatalytic wave at 1.4-1.6 V.

In order to get more insights into the new species formed upon cycling, bulk electrolysis experiments at $E_{\text {app }}=1.45 \mathrm{~V}$ for $2 \mathrm{~h}$ were conducted (Figure $4 \mathrm{C}$ ) which involved a charge of 7.93 $\mathrm{C}$ and 4.8 mols of electrons per mol of initial $\mathrm{Ru}(\mathrm{II})$ clearly indicating the presence of an electrocalytic process. The solution generated under these conditions was analyzed by DPV experiments that are shown in Figure 4D. The DPV shows that the waves associated with the initial complex have drastically decreased and a set of new waves appear at $E=0.25 \mathrm{~V}, E=0.46$ $\mathrm{V}, E=0.73 \mathrm{~V}$ and $E=1.03 \mathrm{~V}$. Further as shown by DPV at different $\mathrm{pH}$ all these waves are $\mathrm{pH}$ dependent and therefore involving proton coupled electron transfer (PCET) processes that in turn indicate the presence of $\mathrm{Ru}-\mathrm{OH}_{2}$ groups in the new species generated (Figure $\mathrm{S} 13$ in the $\mathrm{SI}$ ). Finally, a very large an intense wave can be observed at approximately $1.35 \mathrm{~V}$ attributed to the catalytic oxidation of water to dioxygen.

It is important to note that waves at 0.25 and $0.73 \mathrm{~V}$ assigned to [ $\mathrm{Ru}\left(\right.$ " $\left.\left(p d c-\mathrm{K}^{3}-\mathrm{N}^{1} \mathrm{O}^{2}\right)(\mathrm{bpy})\left(\mathrm{H}_{2} \mathrm{O}\right)\right]$, 1-0, species generated from the Coulometry of $1^{11 !}$ coincide with those generated by the Coulometry of $\mathbf{2}^{\prime \prime}$, meaning that one of the transformation processes involves bpy ligand loss as indicated in Scheme 2. Further by checking the potential as a function of $\mathrm{pH}$ we were able to generate a Pourbaix diagram that is presented in the left hand side of Figure 5 . The pka calculated from the slope changes are 4 for $\mathrm{Ru}(\mathrm{II})$ and 11 for $\mathrm{Ru}(\mathrm{III})$ and are gathered in Table 1 together with similar data for related complexes previously described in the literature. The strong sigma donating effect of the pyridil dicaroxylato ligand can be clearly observed on the increase of pka's (10->11 (II); 2->4 (III)) and reduction of the V/IV redox couples when comparing for instance with trpy-bpy-Ru-OH$\cdot{ }^{31}(\mathrm{REF})$

On the other hand, the waves at 0.46 and $1.03 \mathrm{~V}$ are assigned to a new species where a one of the carboxylate arms of $\mathrm{pdc}^{2-}$ is substituted by an oxo group generating the seven coordinated species $\left[\mathrm{Ru}^{\mathrm{IV}}(\mathrm{O})\left(\mathrm{pdc}-\mathrm{r}^{2}-\mathrm{N}^{1} \mathrm{O}^{1}\right)(\mathrm{bpy})_{2}\right], 2-\mathrm{O}$. The Pourbaix diagram obtained for this complex is presented on the right hand side of Figure 5. Here the III/II redox potential is significantly hgiher 
than for $\left[\mathrm{Ru}^{\prime \prime}\left(\text { pdc- } \mathrm{k}^{3}-\mathrm{N}^{1} \mathrm{O}^{2}\right)(\mathrm{bpy})\left(\mathrm{H}_{2} \mathrm{O}\right)\right]^{-}, \mathbf{1 - 0}$, since in the present complex the pdc ${ }^{2-}$ ligand acts in a $\mathrm{k}-\mathrm{N}^{1} \mathrm{O}^{1}$ mode and thus only one of the two anionic charges is directly felt by the Ru center. In sharp contrast the V/IV redox potentials are similar which is due to the cancelling effect of CN7 vs CN6 1 vs. 2 anionic charges, a phenomenon that has been previously described for related Ru-aquo complexes. ${ }^{14}\left(\mathrm{REF},{ }^{31-34}\right)$

The water oxidation catalytic cycles proposed for 1-0 and 2-0, are presented in Scheme 2. The main differentiating feature for the two cat cycles is that for 2-0 the high oxidation state species are CN7 and a dangling carboxylate is ready for an intramolecular proton transfer at the 0-O bond formation step that is generally the rds, and thus radically decreases the energy of activation at this step as has been previously shown for related complexes.

Indeed, a FOWA analysis ${ }^{35-37}$ of the catalytic current (see Figure 6) for the mixture of 1-0 and 2$\mathbf{0}$, gives a TOF ${ }_{\max }$ value for the catalytic process of 2.4-3.4 $\times 10^{3} \mathrm{~s}^{-1}$, for $2-0$, assuming that the initial current at the foot is solely due to the fastest WOC.

Finally, an analysis of the gas phase, of a bulk electrolysis experiments of $1 \mathrm{mM} \mathbf{2}^{11}$ at an applied potential of $1.45 \mathrm{~V}$ for $1.2 \mathrm{~h}$ (4.25 C; 15 mols of electrons/mols of $2^{\text {II; }} 3.5 \mathrm{TN}$ ) confirms the evolution of $\mathrm{O}_{2}$ gas with a Faradaic efficiency of $90 \%$. (see Figure S16)

In conclusion, two new Ru complexes $\left.R u^{\prime \prime \prime}\left(p d c-\mathrm{k}^{3}-\mathrm{N}^{1} \mathrm{O}^{2}\right)(\mathrm{bpy}) \mathrm{Cl}\right], \mathbf{1}^{1 \prime \prime}$, and [Ru"(pdc- $\mathrm{k}^{2}-$ $\left.\left.\mathrm{N}^{1} \mathrm{O}^{1}\right)(\mathrm{bpy})_{2}\right], \mathbf{2}^{\prime \prime}$, are reported that under high anodic potentials evolve towards the formation of Ru-aquo complexes $\left[\mathrm{Ru}{ }^{\prime \prime \prime}\left(p d c-\mathrm{r}^{3}-\mathrm{N}^{1} \mathrm{O}^{2}\right)(\mathrm{bpy})\left(\mathrm{OH}_{2}\right)\right]^{+}, \mathbf{1 - O}$, and $\left[\mathrm{Ru}^{\mathrm{IV}}(\mathrm{O})\left(\mathrm{pdc}-\mathrm{r}^{2}-\mathrm{N}^{1} \mathrm{O}^{1}\right)(\mathrm{bpy})_{2}\right], \mathbf{2}-$ $\mathbf{O}$, that are powerful and rugged water oxidation catalysts. These two complexes operate water oxidation catalysis with active species that involve six coordination for the Ru center in 1-0 and seven coordination in $\mathbf{2 - 0}$. The present work uncovers and highlights the complexity involved in water oxidation catalytic processes when transition metal complexes are exposed to high oxidation potentials needed for water oxidation catalysis.

\section{5-Acknowledgements}

A.L. thanks MINECO, FEDER and AGAUR for grants CTQ2016-80058-R, CTQ2015-73028-EXP, SEV 2013-0319, ENE2016-82025-REDT, CTQ2016-81923-REDC, and 2017-SGR-1631. 
6- Supporting Information. Additional experimental details, electrochemical and spectroscopic data. CIF files for complexes 1"', 2" and 2"' with CCDC numbers 1881914, 1881913 and 1881915 respectively are available at https://www.ccdc.cam.ac.uk/. 
References

1. Lewis, N. S.; Nocera, D. G., Powering the planet: Chemical challenges in solar energy utilization. PNAS 2006, 103 (43), 15729-15735.

2. Berardi, S.; Drouet, S.; Francas, L.; Gimbert-Surinach, C.; Guttentag, M.; Richmond, C.; Stoll, T.; Llobet, A., Molecular artificial photosynthesis. Chem. Soc. Rev. 2014, 43 (22), 7501-7519.

3. Matheu, r. G.-B., P.; Gil-Sepulcre, M.; Ertem, M. Z.; Sala, X.; Gimbert-Suriñach, C.; Llobet, A., A Historical Perspective on the Development of Molecular Water Oxidation Catalysts. Nat. Rev. 2018.

4. Blakemore, J. D.; Crabtree, R. H.; Brudvig, G. W., Molecular catalysts for water oxidation. Chem. Rev. 2015, 115 (23), 12974-13005.

5. Cao, R.; Lai, W.; Du, P., Catalytic water oxidation at single metal sites. Energ. Env. Sci. 2012, 5 (8), 8134-8157.

6. Llobet, A., Molecular water oxidation catalysis: a key topic for new sustainable energy conversion schemes. John Wiley \& Sons: 2014.

7. Garrido-Barros, P.; Gimbert-Suriñach, C.; Matheu, R.; Sala, X.; Llobet, A., How to make an efficient and robust molecular catalyst for water oxidation. Chem. Soc. Rev. 2017, 46 (20), 6088-6098.

8. Tong, L.; Thummel, R. P., Mononuclear ruthenium polypyridine complexes that catalyze water oxidation. Chem. Sci. 2016, 7 (11), 6591-6603.

9. Xie, Y.; Shaffer, D. W.; Concepcion, J. J., O-O Radical Coupling: From Detailed Mechanistic Understanding to Enhanced Water Oxidation Catalysis. Inorg. Chem. 2018.

10. Matheu, R.; Ertem, M. Z.; Benet-Buchholz, J.; Coronado, E.; Batista, V. S.; Sala, X.; Llobet, A., Intramolecular Proton Transfer Boosts Water Oxidation Catalyzed by a Ru Complex. J. Am. Chem. Soc. 2015, 137 (33), 10786-10795.

11. Shaffer, D. W.; Xie, Y.; Szalda, D. J.; Concepcion, J. J., Manipulating the rate-limiting step in water oxidation catalysis by ruthenium bipyridine-dicarboxylate complexes. Inorg. Chem. 2016, 55 (22), 12024-12035.

12. Keidel, A.; López, I.; Staffa, J.; Kuhlmann, U.; Bozoglian, F.; Gimbert-Suriñach, C.; Benet-Buchholz, J.; Hildebrandt, P.; Llobet, A., Electrochemical and Resonance Raman Spectroscopic Studies of Water-Oxidizing Ruthenium Terpyridyl-Bipyridyl Complexes. ChemSusChem 2017, 10 (3), 551-561.

13. Wasylenko, D. J.; Ganesamoorthy, C.; Henderson, M. A.; Koivisto, B. D.; Osthoff, H. D.; Berlinguette, C. P., Electronic modification of the [Rull (tpy)(bpy)(OH2)] 2+ scaffold: Effects on catalytic water oxidation. J. Am. Chem. Soc. 2010, 132 (45), 16094-16106. 
14. Matheu, R.; Ertem, M. Z.; Gimbert-Suriñach, C.; Benet-Buchholz, J.; Sala, X.; Llobet, A., Hydrogen Bonding Rescues Overpotential in Seven-Coordinated Ru Water Oxidation Catalysts. ACS Catal. 2017, 7 (10), 6525-6532.

15. Matheu, r. E., M. Z.; Gimbert-Suriñach, C.; Sala, X.; Llobet, A., Seven Coordinated Molecular Ru-Water Oxidation Catalysts: a Coordination Chemistry Journey. Chem. Rev. 2018.

16. Xie, Y.-F.; Zhu, H.; Shi, H.-T.; Jia, A.-Q.; Zhang, Q.-F., Ruthenium complexes containing pyridine-2,6-dicarboxylato ligands. Inorg. Chim. Acta 2015, 428, 147-153.

17. Duan, L.; $\mathrm{Xu}, \mathrm{Y}$.; Gorlov, M.; Tong, L.; Andersson, S.; Sun, L., Chemical and Photochemical Water Oxidation Catalyzed by Mononuclear Ruthenium Complexes with a Negatively Charged Tridentate Ligand. Chem. Eur. J. 2010, 16 (15), 4659-4668.

18. Daniel, Q.; Duan, L.; Timmer, B. J. J.; Chen, H.; Luo, X.; Ambre, R.; Wang, Y.; Zhang, B.; Zhang, P.; Wang, L.; Li, F.; Sun, J.; Ahlquist, M.; Sun, L., Water Oxidation Initiated by In Situ Dimerization of the Molecular Ru(pdc) Catalyst. ACS Catal. 2018, 8 (5), 4375-4382.

19. Evans, I. P.; Spencer, A.; Wilkinson, G., Dichlorotetrakis(dimethyl sulphoxide)ruthenium(II) and its use as a source material for some new ruthenium(II) complexes. J. Am. Chem. Soc. 1973, (2), 204-209.

20. Data collection and reduction with CrysAlisPro 1.171.39.12b (Rigaku OD.

21. Empirical absorption corrrection using spherical harmonics implemented in Scale3 Abspack scaling algorithm, C. b. R. O., 2015).

22. SHELXT; Sheldrick, G. M., Acta Cryst. 2015, A71, 3-8.

23. SHELXle; C.B. Huebschle, G. M. S. B. D., J.Appl.Cryst. 2011, 44, 1281-1284.

24. Singha Hazari, A.; Ray, R.; Hoque, M. A.; Lahiri, G. K., Electronic Structure and Multicatalytic Features of Redox-Active Bis (arylimino) acenaphthene (BIAN)-Derived Ruthenium Complexes. Inorg. Chem. 2016, 55 (16), 8160-8173.

25. Matheu, R.; Ghaderian, A.; Francas, L.; Chernev, P.; Ertem, M.; Benet-Buchholz, J.; Batista, V.; Haumann, M.; Gimbert-Suriñach, C.; Sala, X., The Behavior of the Ru-bda Water Oxidation Catalysts at Low Oxidation States. Chem. Eur. J. 2018.

26. Neudeck, S.; Maji, S.; López, I.; Dechert, S.; Benet-Buchholz, J.; Llobet, A.; Meyer, F., Establishing the Family of Diruthenium Water Oxidation Catalysts Based on the Bis (bipyridyl) pyrazolate Ligand System. Inorg. Chem. 2016, 55 (5), 2508-2521.

27. Ohzu, S.; Ishizuka, T.; Hirai, Y.; Jiang, H.; Sakaguchi, M.; Ogura, T.; Fukuzumi, S.; Kojima, T., Mechanistic insight into catalytic oxidations of organic compounds by ruthenium (IV)-oxo complexes with pyridylamine ligands. Chem. Sci. 2012, 3 (12), 3421-3431.

28. Kaim, W.; Lahiri, G. K., Unconventional Mixed-Valent Complexes of Ruthenium and Osmium. Angew. Chem. Int. Ed. 2007, 46 (11), 1778-1796. 
29. Mandal, A.; Hoque, M. A.; Grupp, A.; Paretzki, A.; Kaim, W.; Lahiri, G. K., Analysis of Redox Series of Unsymmetrical 1, 4-Diamido-9, 10-anthraquinone-Bridged Diruthenium Compounds. Inorg. Chem. 2016, 55 (5), 2146-2156.

30. Kaveevivitchai, N.; Kohler, L.; Zong, R.; El Ojaimi, M.; Mehta, N.; Thummel, R. P., A Ru (II) bis-terpyridine-like complex that catalyzes water oxidation: The influence of steric strain. Inorg. Chem. 2013, 52 (18), 10615-10622.

31. Takeuchi, K. J.; Thompson, M. S.; Pipes, D. W.; Meyer, T. J., Redox and spectral properties of monooxo polypyridyl complexes of ruthenium and osmium in aqueous media. Inorg. Chem. 1984, 23 (13), 1845-1851.

32. Llobet, A.; Doppelt, P.; Meyer, T. J., Redox properties of aqua complexes of ruthenium(II) containing the tridentate ligands 2,2':6',2"-terpyridine and tris(1-pyrazolyl)methane. Inorg. Chem. 1988, 27 (3), 514-520.

33. Mognon, L.; Benet-Buchholz, J.; Llobet, A., Single Site Isomeric Ru WOCs with an Electron-Withdrawing Group: Synthesis, Electrochemical Characterization, and Reactivity. Inorg. Chem. 2015, 54 (24), 11948-11957.

34. Maji, S.; López, I.; Bozoglian, F.; Benet-Buchholz, J.; Llobet, A., Mononuclear Ruthenium-Water Oxidation Catalysts: Discerning between Electronic and Hydrogen-Bonding Effects. Inorg. Chem. 2013, 52 (7), 3591-3593.

35. Costentin, C.; Drouet, S.; Robert, M.; Savéant, J.-M., Turnover Numbers, Turnover Frequencies, and Overpotential in Molecular Catalysis of Electrochemical Reactions. Cyclic Voltammetry and Preparative-Scale Electrolysis. J. Am. Chem. Soc. 2012, 134 (27), 11235-11242. 36. Costentin, C.; Drouet, S.; Robert, M.; Savéant, J.-M., A Local Proton Source Enhances $\mathrm{CO}_{2}$ Electroreduction to $\mathrm{CO}$ by a Molecular Fe Catalyst. Science. 2012, 338 (6103), 90-94.

37. Matheu, R.; Neudeck, S.; Meyer, F.; Sala, X.; Llobet, A., Foot of the wave analysis for mechanistic elucidation and benchmarking applications in molecular water oxidation catalysis. ChemSusChem 2016, 9 (23), 3361-3369.

38. Sens, C.; Rodríguez, M.; Romero, I.; Llobet, A.; Parella, T.; Benet-Buchholz, J., Synthesis, Structure, and Acid-Base and Redox Properties of a Family of New Ru(II) Isomeric Complexes Containing the Trpy and the Dinucleating Hbpp Ligands. Inorg. Chem. 2003, 42 (25), 8385-8394. 39. Tong, L.; Inge, A. K.; Duan, L.; Wang, L.; Zou, X.; Sun, L., Catalytic Water Oxidation by Mononuclear Ru Complexes with an Anionic Ancillary Ligand. Inorg. Chem. 2013, 52 (5), 25052518.

40. Duan, L.; Bozoglian, F.; Mandal, S.; Stewart, B.; Privalov, T.; Llobet, A.; Sun, L., A molecular ruthenium catalyst with water-oxidation activity comparable to that of photosystem II. Nat. Chem. 2012, 4, 418. 
Table1. Thermodynamic and Catalytic Data for Ru-pdc and for Related Ru Complexes Described in the Literature at $\mathrm{pH}=7.0$.

\begin{tabular}{|c|c|c|c|c|c|c|c|c|c|}
\hline \multirow[b]{2}{*}{ Entry } & \multirow[b]{2}{*}{ Complexes $^{\mathrm{a}}$} & \multicolumn{3}{|c|}{$E_{1 / 2}(\mathrm{~V})$ vs NHE } & & \multicolumn{3}{|c|}{$\mathrm{p} K_{\mathrm{a}}$} & \multirow[b]{2}{*}{$\mathrm{TOF}^{\mathrm{c}, \mathrm{d}}$} \\
\hline & & V/IV & IV/III & III/II & ${ }^{\mathrm{b}} \Delta E$ & $\mathrm{Ru}^{\prime \prime}-\mathrm{OH}_{2}$ & $\mathrm{Ru}^{\prime \prime \prime}-\mathrm{OH}_{2}$ & $\mathrm{Ru}^{\mathrm{IV}}-\mathrm{OH}$ & \\
\hline $1^{31}$ & {$\left[\mathrm{Ru}(\operatorname{trpy})(\mathrm{bpy})\left(\mathrm{H}_{2} \mathrm{O}\right)\right]^{2+}$} & 1.86 & 0.83 & 0.72 & 110 & 9.8 & 1.7 & - & $1.5 \times 10^{1}$ \\
\hline $2^{32}$ & Cis-[Ru(trpy)(pic) $\left.\left(\mathrm{H}_{2} \mathrm{O}\right)\right]^{1+}$ & - & 0.80 & 0.62 & 180 & 10.0 & 3.7 & - & - \\
\hline $3^{32}$ & Trans- $\left[\mathrm{Ru}(\operatorname{trpy})(\mathrm{pic})\left(\mathrm{H}_{2} \mathrm{O}\right)\right]^{1+}$ & - & 0.69 & 0.45 & 240 & 10 & 2.0 & - & - \\
\hline $4^{38}$ & out-[Ru(Hbpp)(trpy)($\left.\left(\mathrm{H}_{2} \mathrm{O}\right)\right]^{2+}$ & - & 0.85 & 0.52 & 370 & 11.1 & 2.8 & - & - \\
\hline $5^{39}$ & {$\left[\mathrm{Ru}(\mathrm{bpc})(\mathrm{bpy})\left(\mathrm{H}_{2} \mathrm{O}\right)\right]^{1+}$} & - & - & 0.56 & - & 10.6 & 2.6 & - & $1.6 \times 10^{2}$ \\
\hline $6^{e}$ & {$\left[\mathrm{Ru}(\mathrm{pdc})(\mathrm{bpy})\left(\mathrm{H}_{2} \mathrm{O}\right)\right]^{1+}$} & 1.41 & 0.73 & 0.25 & 480 & 11 & 4 & - & \\
\hline $7^{40}$ & $\left.\mathrm{Ru}(\mathrm{bda})(\mathrm{isq})_{2}\left(\mathrm{H}_{2} \mathrm{O}\right)\right]$ & 1.11 & 0.88 & 0.55 & 330 & 5.5 & 12.9 & - & $3.0 \times 10^{2}$ \\
\hline $8^{10}$ & {$\left[\mathrm{Ru}(\mathrm{tda})(\mathrm{py})_{2} \mathrm{OH}\right]$} & 1.43 & 0.87 & 0.70 & 170 & - & - & $\mathrm{Ru}^{\mathrm{IV}}(5.5)$ & $8.0 \times 10^{3}$ \\
\hline $9^{e}$ & {$\left[\mathrm{Ru}(\mathrm{pdc})(\mathrm{bpy})_{2} \mathrm{OH}\right]$} & 1.47 & 0.93 & & & - & - & $\mathrm{Ru}^{\mathrm{IV}}(5.0)-$ & $3.4 \times 10^{3}$ \\
\hline
\end{tabular}

'aigand abbreviations: trpy $=2,2^{\prime}: 6^{\prime}, 2^{\prime \prime}$-terpyridine, bpy $=2,2^{\prime}$-bipyridine, pic $=2$-picolinate, $\mathrm{Hbpp}=3,5$-bis $\left(2\right.$-pyridyl)pyrazole, bpc $=2,2^{\prime}$-bipyridine-6-carboxylate, pdc $=$ 2,6-pyridinedicarboxylate, bda $=2,2^{\prime}$-bipyridine-6,6'-dicarboxylate, tda $=2,2^{\prime}: 6^{\prime}, 2^{\prime \prime}$-terpyridine-6,6"-dicarboxylate, py $=$ pyridine. ${ }^{b} \Delta E=E(I V / I I I)-E(I I I / I I) . ~{ }^{c} T O F$ stands for initial Turn Over Frequencies in cycles per second. These values are extracted for the catalytic reactions involving $1.0 \mathrm{mM}$ Cat/100 mM Ce(IV)in a 0.1 M triflic acid solution with a total volume of $2 \mathrm{~mL}$ (entry 1, 5 and 7). ${ }^{\mathrm{d}}$ TOF stands for Maximum Turn Over Frequencies per second. These value has been extracted from Foot of the Wave Analysis of CV and DPV experiment in $\mathrm{pH} 7$ (entry 8 and 9 ). ${ }^{\mathrm{e}}$ this work. 
Scheme 1. Synthetic scheme and labelling.

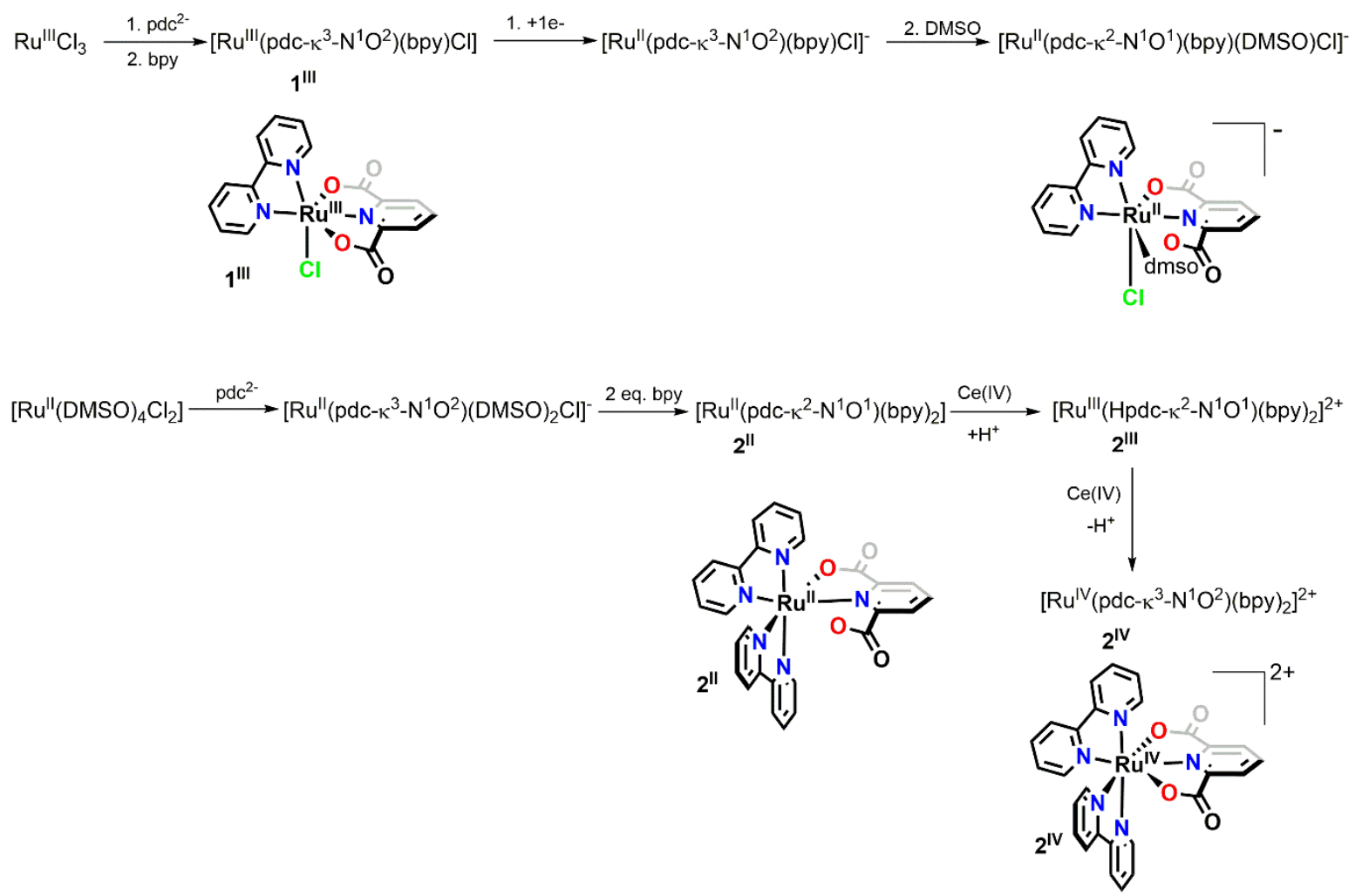




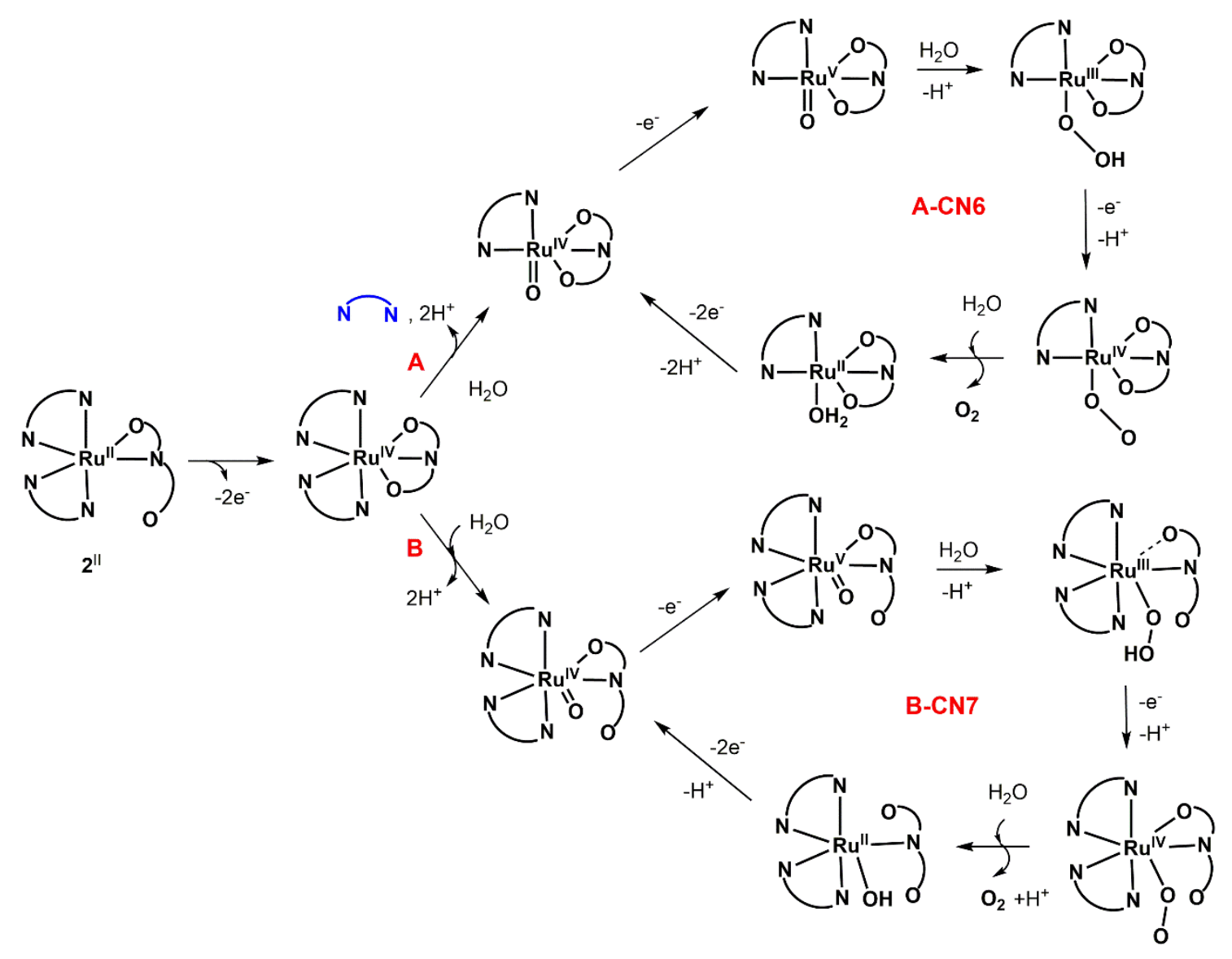

Scheme 2. Generation of water oxidation catalytically active species from $\mathbf{2}^{\prime \prime}$. 
A)

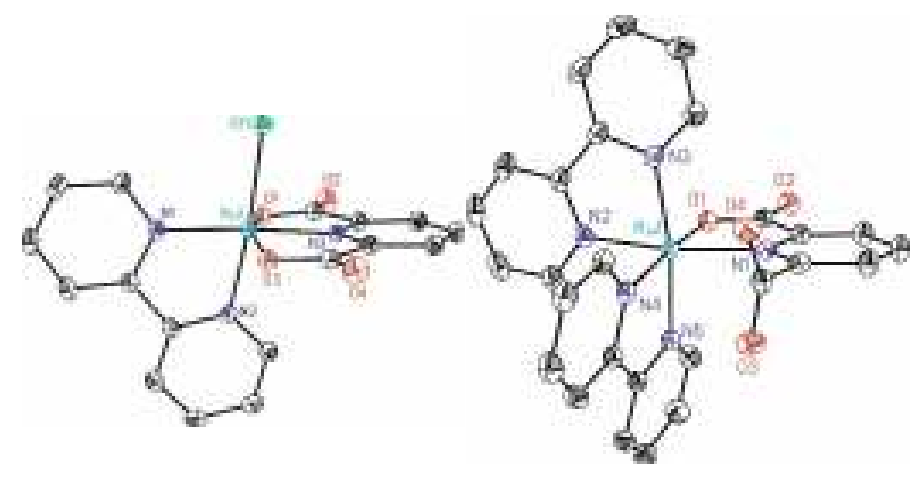

C)

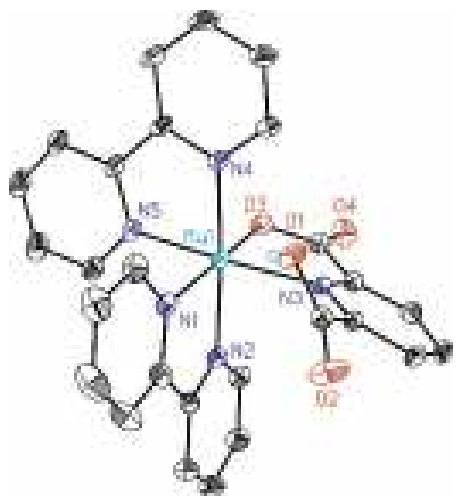

Figure 1. ORTEP plots at $50 \%$ probability for $\left[R u^{\prime \prime \prime}\left(p d c-\mathrm{K}^{3}-\mathrm{N}^{1} \mathrm{O}^{2}\right)(\mathrm{bpy}) \mathrm{Cl}\right], \mathbf{1}^{\prime \prime \prime}(\mathrm{A}),\left[R \mathrm{u}^{\prime \prime}\left(\mathrm{pdc}-\mathrm{K}^{2}-\right.\right.$ $\left.\left.\mathrm{N}^{1} \mathrm{O}^{1}\right)(\mathrm{bpy})_{2}\right], 2^{\prime \prime}(\mathrm{B})$ and $\left[\mathrm{Ru}\right.$ "(Hpdc- $\left.\left.\mathrm{K}^{2}-\mathrm{N}^{1} \mathrm{O}^{1}\right)(\mathrm{bpy})_{2}\right]^{2+}, \mathbf{2}^{\mathrm{II \prime}}(\mathrm{C})$.

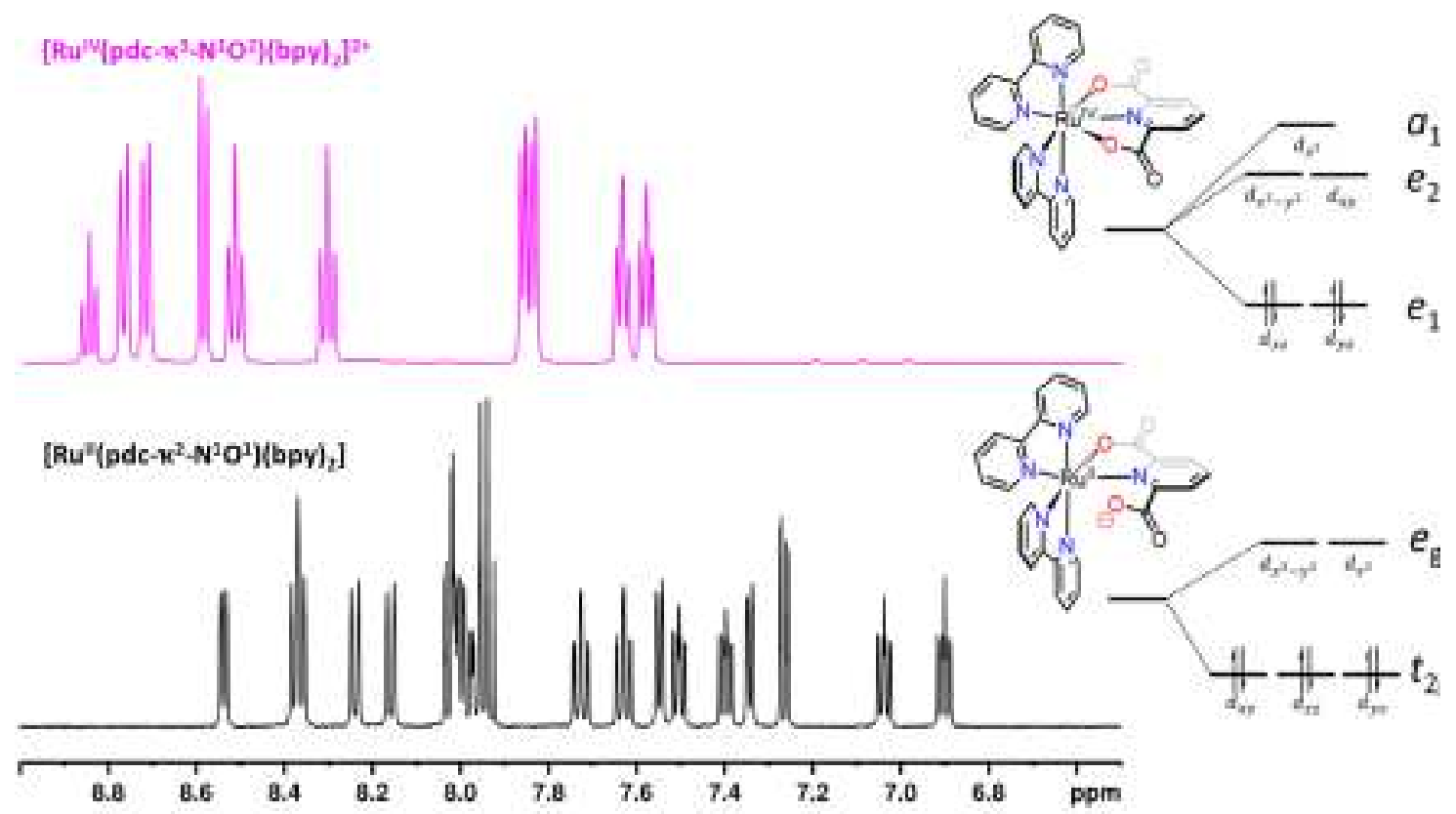

Figure 2. ${ }^{1} \mathrm{H}$ NMR $\left(500 \mathrm{MHz}, 298 \mathrm{~K},\left[\mathrm{~d}_{2}\right]\right.$-water) of $\left[\mathrm{Ru}^{\prime \prime}\left(\mathrm{pdc}-\mathrm{k}^{2}-\mathrm{N}^{1} \mathrm{O}^{1}\right)(\mathrm{bpy})_{2}\right], \mathbf{2}^{\prime \prime}$ (black, bottom) and $\left[\mathrm{Ru}^{\mathrm{IV}}\left(\mathrm{pdc}-\mathrm{K}^{3}-\mathrm{N}^{1} \mathrm{O}^{2}\right)(\mathrm{bpy})_{2}\right]^{2+}, \mathbf{2}^{\mathrm{IV}}$ (blue, top). The Crystal Field Splitting of d-orbitals and electronic configuration under 6-coordination-octahedral $\left(O_{h}\right)$ or 7-coordinated pentagonal bipyramidal $\left(D_{5 h}\right)$ geometries are indicated next to each spectrum. 

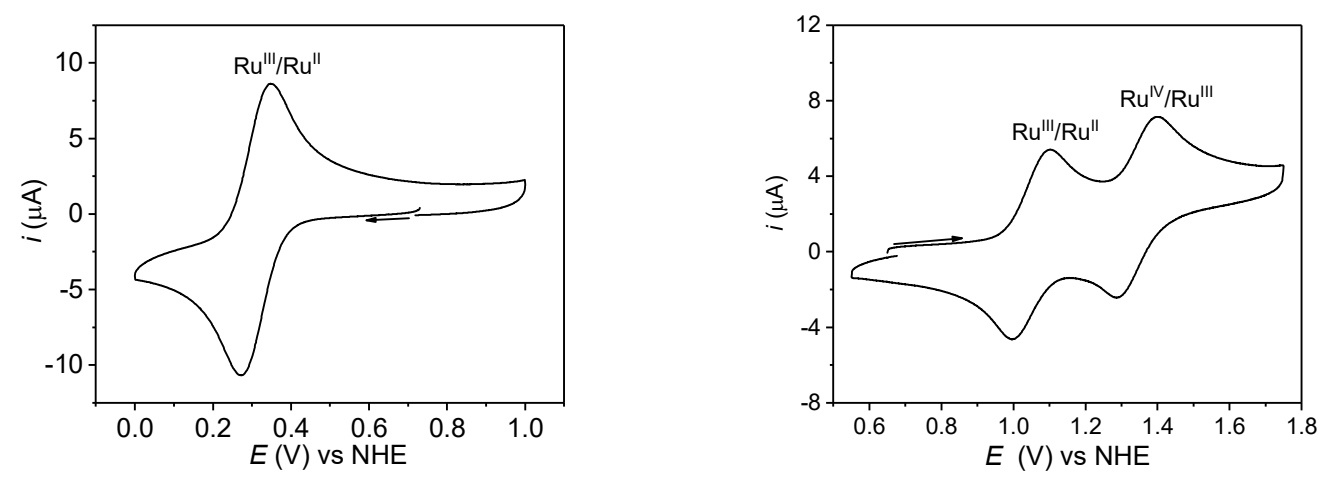

Figure 3. Cyclic voltammetry experiments in dichloromethane-0.1M $\left[(n-\mathrm{Bu})_{4} \mathrm{~N}\right]\left[\mathrm{PF}_{6}\right]$ of a $1 \mathrm{mM}$ solution of for $\left[R u^{\prime \prime \prime}\left(p d c-k^{3}-N^{1} O^{2}\right)(b p y) C l\right], 1^{1 " \prime \prime}$ (left) and $\left[R u^{\prime \prime}\left(p d c-k^{2}-N^{1} O^{1}\right)(b p y)_{2}\right], 2^{\prime \prime}$ (right). WE: glassy carbon disk; $\mathrm{CE}$ : platinum disk; $\mathrm{RE}: \mathrm{Hg} / \mathrm{Hg}_{2} \mathrm{SO}_{4}$. Scan rate $=100 \mathrm{mV} / \mathrm{s}$. 

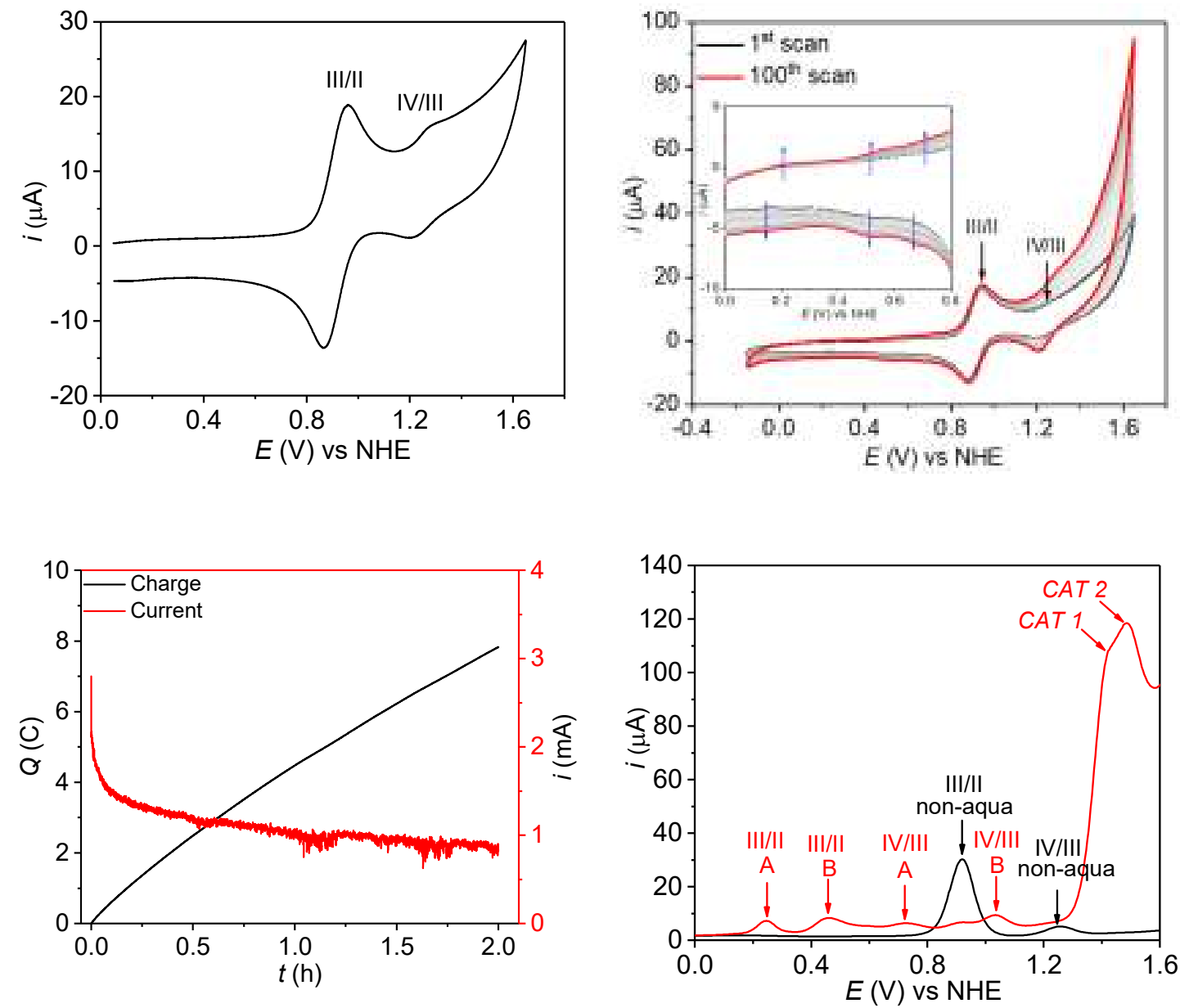

Figure 4. A, CV of a pH 7 phbf solution of $1 \mathrm{mM} \mathrm{2".} \mathrm{B,} 100$ consecutive CV cycles. Inset, enlargement of the $0-0.8 \mathrm{~V}$ range. The blue arrows indicate small new waves growing. $C$, bulk electrolysis of a pH 8 phbf solution of $2 \mathrm{mM} \mathrm{2"} \mathrm{at} E_{\text {app }}=1.45 \mathrm{~V}$ for $2 \mathrm{~h} . \mathrm{D}, \mathrm{DPV}$ of a pH $7 \mathrm{phbf}$ solution of $2 \mathrm{mM} \mathbf{2}^{\prime \prime}$ (black) and of the solution obtained after the bulk electrolysis in C adjusted to $\mathrm{pH} 7$ (red). 

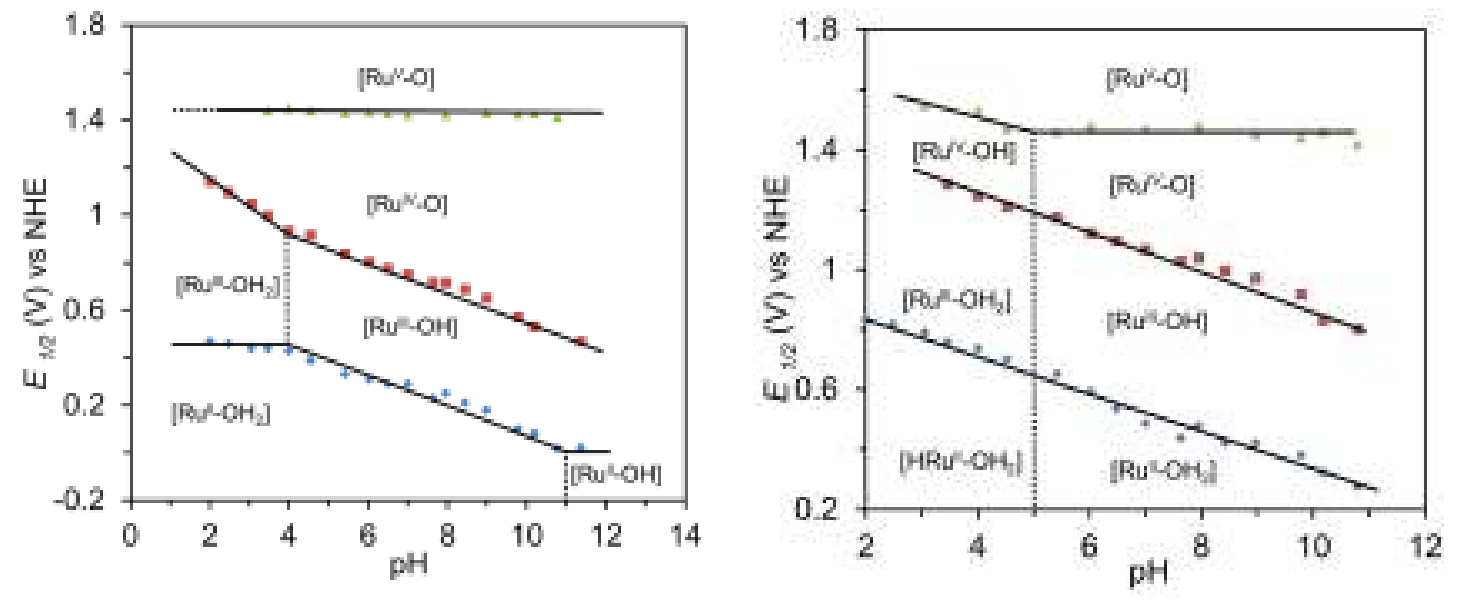

Figure 5. Pourbaix diagrams of $\left[\mathrm{Ru}-\mathrm{OH}_{2}\right]$ species derived from bulk electrolysis of $\mathbf{2}^{\prime \prime}$. Left, 10; Right, 2-0. The black solid lines indicate the redox potentials for the different redox couples, whereas the dashed vertical lines indicate the pKa. The zone of stability of the different species is indicated only with the Ru symbol, its oxidation state, and its degree of protonation of the aqua ligand. For instance, " $\mathrm{Ru}(\mathrm{V})=\mathrm{O}$ " is used to indicate the zone of stability of $\left[\mathrm{Ru}^{\mathrm{v}}(\mathrm{O})\left(\mathrm{pdc}-\mathrm{K}^{3}-\mathrm{N}^{1} \mathrm{O}^{2}\right)(\mathrm{bpy})\right]^{+}$for the 1-O derived species (left) and $\left[\mathrm{Ru}^{\mathrm{V}}(\mathrm{O})\left(\mathrm{pdc}-\mathrm{K}^{3}-\right.\right.$ $\left.\left.\mathrm{N}^{1} \mathrm{O}^{1}\right)(\mathrm{bpy})_{2}\right]^{+}$for the 2-O derived species (right). 


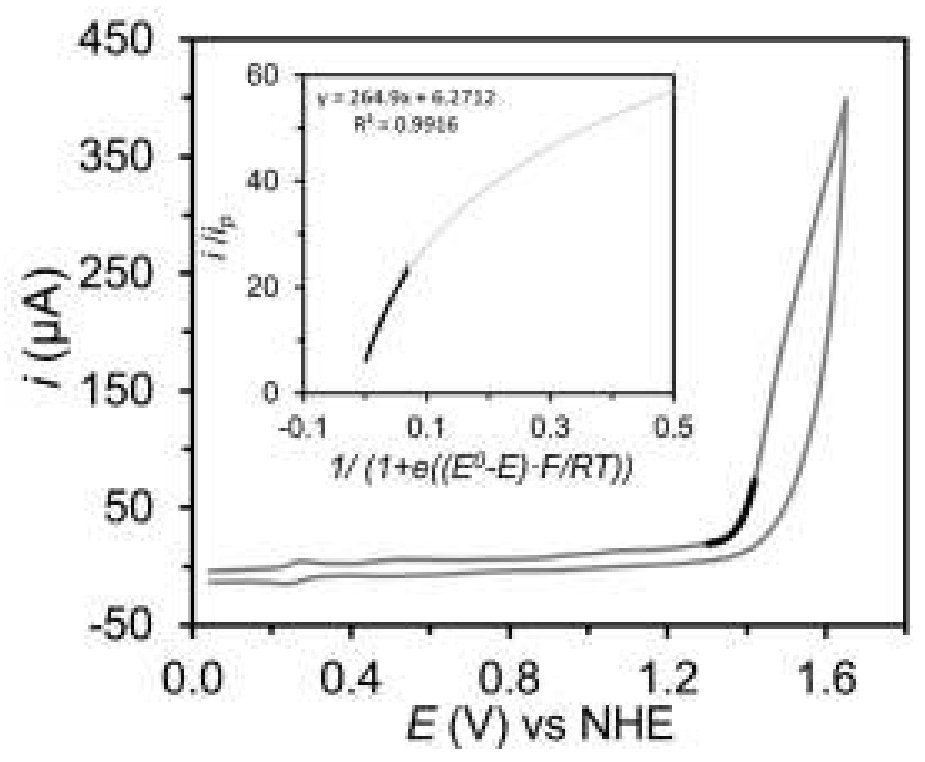

Figure 6. $\mathrm{CV}$ of a mixture of $0.92 \mathrm{mM}\left[\mathrm{Ru}\left(\mathrm{pdc}-\mathrm{K}^{3}-\mathrm{N}^{1} \mathrm{O}^{2}\right)(\mathrm{bpy})\left(\mathrm{H}_{2} \mathrm{O}\right)\right], 1-\mathrm{O}$ and $1.08 \mathrm{mM}$ $\left[\mathrm{Ru}^{\mathrm{IV}}(\mathrm{O})\left(\mathrm{pdc}-\mathrm{K}^{2}-\mathrm{N}^{1} \mathrm{O}^{1}\right)(\mathrm{bpy})_{2}\right], 2-0$ at $\mathrm{pH} 7.0$ phbf. Inset: FOWA plot of the catalytic current. The gray line represents the experimental data used for the FOWA analysis, and the black solid line shows the experimental data used for the extraction of TOF $\max$ 